\title{
Hepatitis B virus in Pakistan: A systematic review of prevalence, risk factors, awareness status and genotypes
}

Muhammad Ali, Muhammad Idrees*, Liaqat Ali, Abrar Hussain, Irshad Ur Rehman, Sana Saleem, Samia Afzal, Sadia Butt

\begin{abstract}
In Pakistan, there are estimated 7-9 million carriers of hepatitis B virus (HBV) with a carrier rate of 3-5\%. This article reviews the available literature about the prevalence, risk factors, awareness status and genotypes of the HBV in Pakistan by using key words; HBV prevalence, risk factors, awareness status and genotypes in Pakistani population in PubMed, PakMediNet, Directory of Open Access Journals (DOAJ) and Google Scholar. One hundred and six different studies published from 1998 to 2010 were included in this study. Weighted mean and standard deviation were determined for each population group. The percentage of hepatitis B virus infection in general population was $4.3318 \% \pm 1.644 \%$, healthy blood donors $(3.93 \% \pm 1.58 \%)$, military recruits $(4.276 \% \pm 1.646 \%)$, healthcare persons (3.25\% $\pm 1.202 \%)$, pregnant women $(5.872 \% \pm 4.984)$, prisoners $(5.75 \% \pm 0.212 \%)$, surgical patients $(7.397 \%$ $\pm 2.012 \%)$, patients with cirrhosis $(28.87 \% \pm 11.90 \%)$, patients with HCC $(22 \% \pm 2.645 \%)$, patients with hepatitis $(15.896 \% \pm 14.824 \%)$, patients with liver diseases $(27.54 \% \pm 6.385 \%)$, multiple transfused patients $(6.223 \% \pm 2.121 \%)$, opthalmic patients (3.89\% $\pm 1.004 \%)$ and users of injectable drugs (14.95\% $\pm 10.536 \%)$. Genotype D (63.71\%) is the most prevalent genotype in Pakistani population. Mass vaccination and awareness programs should be initiated on urgent basis especially in populations with HBV infection rates of more than $5 \%$.
\end{abstract}

\section{Introduction}

Hepatitis B virus (HBV) infection is a major global health problem [1-3], especially in Asia, Africa, southern Europe and Latin America [4]. About 2 billion people are infected with HBV worldwide [2,4,5], and 400 million among them are suffering from chronic HBV infection [6]. Pakistan is highly endemic with HBV [7] with nine million people infected with HBV [8] and its infection rate is on a steady rise [9]. The reason may be the lack of proper health facilities, poor economical status and less public awareness about the transmission of major communicable diseases including $\mathrm{HBV}, \mathrm{HCV}$ and HIV [6].

The clinical course and sequel of chronic hepatitis vary among individuals. Infection with HBV leads to a wide spectrum of clinical presentations, ranging from

\footnotetext{
* Correspondence: idreeskhan96@yahoo.com Division of Molecular Virology, National Centre of Excellence in Molecular Biology, University of the Punjab, 87-West Canal Bank Road, Thokar Niaz Baig, Lahore, Pakistan
}

(c) 2011 Ali et al; licensee BioMed Central Ltd. This is an Open Access article distributed under the terms of the Creative Commons Attribution License (http://creativecommons.org/licenses/by/2.0), which permits unrestricted use, distribution, and reproduction in any medium, provided the original work is properly cited. asymptomatic carrier state to acute self-limiting infection or fulminant hepatic failure, chronic hepatitis with progression to cirrhosis, and hepatocellular carcinoma (HCC) [2].

Studies are too limited to give a clear picture of the prevalence of HBV at the National level, especially among otherwise healthy individuals. Most previous studies targeted different small groups of individuals with some clinical indications therefore; these do not accurately reflect the overall prevalence in Pakistan $[7,8]$. The present article briefly presents the prevalence, risk factors associated with HBV transmission, awareness status and HBV genotypes prevalent in Pakistani population.

\section{Literature Search and inclusion criteria}

Articles were searched in PubMed, PakMediNet, Directory of Open Access Journals (DOAJ) and Google Scholar by using keywords; Hepatitis B virus in Pakistan, Prevalence of HBV in Pakistan, HBV in Blood donors, Hepatitis B virus in general population, HBV in Pakistani healthcare workers, HBV in surgical patients, HBV 
infection in women and children, HBV infection in prisoners, $\mathrm{HBV}$ in diseased population in Pakistan, $\mathrm{HBV}$ in injection drug users, epidemiology of HBV in Pakistan, HBV genotypes in Pakistan and awareness about HBV in Pakistani population. Two hundreds and twenty nine different studies (articles/repots) were obtained from the literature search, out of which 106 published from 1998 to 2010 were included in the present review. Studies full filling the following criteria were included: 1) Samples were collected from Pakistani individuals. 2) An obvious description of the methods of detection of HBV infection and genotyping. 3) Information about the number of individuals studied and their residing area were reported. 4) Studies reporting risk factors and awareness status in Pakistani population were included to discuss the HBV prevalence in different population groups.

\section{Analysis}

Studies showing percent prevalence of HBV infection in different population are shown in table 1, 2, 3 and 4, while table 5 shows the percentage of different genotypes prevalent in Pakistan. The percent prevalence in the different population groups are presented in mean \pm standard deviation (with 95\% confidence interval).

Formula used for determination of mean prevalence in each population group

$$
\mu=\left(\Sigma x_{i}\right) / N
$$

Formula used for determination of standard deviation (SD) in each population group

$$
\sigma=\sqrt{\frac{1}{N} \sum_{i=1}^{N}\left(x_{i}-\mu\right)^{2}}
$$

Where " $x$ " is the percent HBV prevalence reported in each study and "N" is the total number of studies in the population groups.

\section{HBV prevalence in various population groups}

\section{General population (healthy population)}

Eleven different studies reported the percent prevalence rates of hepatitis $\mathrm{B}$ virus of in general population as $4.3318 \% \pm 1.644 \%(2.46 \%-8.06 \%)$ [6-8,10-17], while six different studies involving healthy recruits showed the prevalence rate of $4.276 \% \pm 1.646 \%$. [18-23]. HBV prevalence of $5.75 \% \pm 0.212 \%$ was observed in prisoners $[24,25]$. Fourteen different studies showed the prevalence rate of $3.93 \% \pm 1.58 \%$ in healthy blood donors in Pakistan [26-39]. HBV prevalence of $9.0 \%$ has been reported in professional blood donors [40]. Two different studies showed the prevalence of HBV in health care workers as $3.25 \% \pm 1.202 \%[41,42]$. Nine studies showed the HBV prevalence of $5.872 \% \pm 4.984 \%$ in pregnant women [43-51], while two different studies demonstrated $1.92 \% \pm 0.169 \%$ prevalence in children $[52,53]$. A very high frequency of $\geq 12 \% \mathrm{HBV}$ infection in pregnant females has been reported in Bahawalpur, Hyderabad and Rahim Yar Khan regions $[47,49,50]$. Up to $21 \%$ of the children born of HBV infected females were infected [47], while Kazmi et al. [54] showed a high prevalence of $90 \%$ in children born of $\mathrm{HBV}$ positive mothers. Quddus et al. [55] showed HBV prevalence of 8.3\% in Afghan refuges residing in Pakistan. Anwar et al. [56] showed a high prevalence rate of HBV that was $11.65 \%$ in female prostitutes in Lahore, Pakistan. Frequency of viral hepatitis in blood donors is higher in Bahawalpur as compared to rest of the world [33].

These studies show that Southern Punjab, Interior Sindh, District Tatta, Kurrum agency and some areas of Lahore have very high $\mathrm{HBV}$ prevalence of $>5 \%$, hence mass vaccination and awareness programs in these areas on urgent basis is suggested.

\section{Surgical patients}

Four different studies showed $7.397 \% \pm 2.012 \% \mathrm{HBV}$ prevalence rates in patients undergoing surgery [57-60]. The lack of routine serological screening in Pakistani hospitals prior to surgery is one of the factors responsible for increased disease transmission [59]. It is recommended that every case undergoing surgery should be screened for hepatitis B and C virus infections [61].

Patients with hepatitis, liver diseases, HCC and cirrhosis Four different studies showed the percent HBV prevalence of $28.87 \% \pm 11.90 \%$ in patients with cirrhosis [62-65] while $22 \% \pm 2.645 \% \mathrm{HBV}$ prevalence was shown by three different studies in patients with HCC [66-68]. Five studies in patients with hepatitis showed the percent prevalence of $15.896 \% \pm 14.824 \%$ [69-73] while four different studies in patients with different liver diseases showed the prevalence of $\mathrm{HBV}$ as $27.54 \% \pm$ $6.385 \%$ [74-77].

\section{Muti-tranfused population (thalassemic and hemophilic patients)}

Thalassemic and hemophilic patients require life-long blood transfusions, so it is necessary to obtain screened blood from a reputable source, because the multitransfused population is more prone to blood-borne pathogens [78]. Four different reports showed percent HBV infection of $6.223 \% \pm 2.121 \%$ in multi-tranfused population [79-82].

\section{Intravenous drug users (IDU)}

Pakistan is estimated to have 4 to 4.8 million drug users with 180,000 IDUs [83]. Strathdee et al. [84] observed 
Table 1 Prevalence of HBV in general population, young recruits and prisoners

\begin{tabular}{|c|c|c|c|c|c|c|}
\hline Population type & Region & Methods & $\begin{array}{l}\text { Population } \\
\text { size }\end{array}$ & $\begin{array}{l}\text { HBV } \\
(\%)\end{array}$ & HBV marker & Reference \\
\hline \multirow[t]{11}{*}{$\begin{array}{l}\text { General } \\
\text { population }\end{array}$} & Lahore & ELISA & 992 & $8.06 \%$ & $\mathrm{HBsAg}$ & $\begin{array}{l}\text { Nafees et al. [10] } \\
2009\end{array}$ \\
\hline & Larkana & $I C T$, ELISA & 200 & $4.8 \%$ & $\mathrm{HBsAg}$ & $\begin{array}{l}\text { Shaikh et al. [11] } \\
2009\end{array}$ \\
\hline & Lahore & $\mathrm{ICT}$ & 203 & 2.46 & HBsAg & $\begin{array}{l}\text { Tanveer et al. [12] } \\
2008\end{array}$ \\
\hline & Karachi & ICT, ELISA. & 4000 & $4.5 \%$ & $\mathrm{HBsAg}$ & $\begin{array}{l}\text { Noorali et al. [7] } \\
2008\end{array}$ \\
\hline & Southern Punjab & ICT/ELISA & 1821 & $5.9 \%$ & HBsAg & $\begin{array}{l}\text { Mirza et al. [13] } \\
2007\end{array}$ \\
\hline & Karachi & $I C T, E L I S A$ and PCR. & 3820 & $4.5 \%$ & HBsAg \& DNA & $\begin{array}{l}\text { Hakim et al. [8] } \\
2008\end{array}$ \\
\hline & Islamabad & $\begin{array}{l}\text { AxSym HBsAg, CORE\& AUSAB } \\
\text { MEIA }\end{array}$ & 1300 & $4 \%$ & $\begin{array}{l}\mathrm{HBsAg} \text {, anti } \mathrm{HBs} \text {, anti } \\
\mathrm{HBC}\end{array}$ & Alam et al. [6] 2007 \\
\hline & Central Punjab & $I C T$, ELISA & 2038 & $4.83 \%$ & HBsAg & $\begin{array}{l}\text { Alam et al. [14] } \\
2006\end{array}$ \\
\hline & Rawalpindi & ELISA & 665 & $3 \%$ & HBsAg & $\begin{array}{l}\text { Farooq et al. [15] } \\
2005\end{array}$ \\
\hline & Lahore & $\mathrm{ICT}$ & 757 & $2.6 \%$ & HBsAg & $\begin{array}{l}\text { Amin et al. [16] } \\
2004\end{array}$ \\
\hline & Karachi & $I C T$, ELISA & 200 & $3 \%$ & HBsAg & $\begin{array}{l}\text { Qasmi et al. [17] } \\
2000\end{array}$ \\
\hline \multirow[t]{6}{*}{ Recruitments } & Rural Areas of Pakistan & $I C T$, ELISA & 3320 & $4.5 \%$ & HBsAg & $\begin{array}{l}\text { Azam et al. [18] } \\
2009\end{array}$ \\
\hline & Interior Sindh & ICT, ELISA & 5237 & $7.39 \%$ & $\mathrm{HBsAg}$ & $\begin{array}{l}\text { Malik et al. [19] } \\
2008\end{array}$ \\
\hline & $\begin{array}{l}\text { Recruits from all over } \\
\text { Pakistan }\end{array}$ & ICT, ELISA & 2558 & $2.8 \%$ & $\mathrm{HBsAg}$ & $\begin{array}{l}\text { Sherif \& Tariq, [20] } \\
2006\end{array}$ \\
\hline & Mardan & ICT, ELISA & 15550 & $3.24 \%$ & $\mathrm{HBsAg}$ & $\begin{array}{l}\text { Mirza et al. [21] } \\
2006\end{array}$ \\
\hline & All areas of Pakistan & ICT, ELISA & 4552 & $4.2 \%$ & $\mathrm{HBsAg}$ & $\begin{array}{l}\text { Hussain et al. [22] } \\
2005\end{array}$ \\
\hline & All areas of Pakistan & ICT, ELISA & 5371 & $3.53 \%$ & $\mathrm{HBsAg}$ & Ali et al. [23] 2002 \\
\hline \multirow[t]{2}{*}{ Prisoners } & Karachi & ELISA & 365 & $5.9 \%$ & $\mathrm{HBs} \mathrm{Ag}$ & Kazi et al. [24] 2010 \\
\hline & Bahawalpur & ICT, ELISA & 2086 & $5.6 \%$ & $\mathrm{HBs} \mathrm{Ag}$ & $\begin{array}{l}\text { Fayyaz et al. [25] } \\
2006\end{array}$ \\
\hline
\end{tabular}

ELISA: Enzume linked immunosorbant assay; HBsAg: hepatitis B surface antigen; ICT: Immuno-chromatographic Test, MEIA: Microparticle Enzyme Immunoassay, HBsAg: hepatitis B surface antigen.

significant increase in needle sharing in IDUs since 2001. Among them Afghan refugees have higher levels of needle sharing as compared to the local IDUs [85]. Two different reports showed a very high HBV prevalence of $14.95 \% \pm 10.536 \%$ in injection drug users $[86,87]$.

\section{Patients with other diseases}

Two different reports show the prevalence of HBV in ophthalmic patients to be $3.89 \% \pm 1.004 \%[88,89]$, percent prevalence of HBV was $12.4 \%$ in patients on hemodialysis [90], 26\% in psychiatric patients [91], 10.2\% in patients advised for liver function tests [92], 1.5\% in patients with dermatoses caused by lichen planus [93] and $2.02 \%$ in orthopedics patients [94]. High prevalence among psychiatric patients could be due to razor sharing, facial and armpit shaving from barbers and carelessness during injuries.

\section{Genotypes}

Hepatitis B virus exists in eight different genotypes (A$\mathrm{H})$ and its prevalence differs with differs by geography and ethnicity [95]. Ten different studies (Table 5) conducted at different regions of Pakistan showed that the most prevalent HBV genotype in Pakistan is genotype D with overall prevalence rate of $63.71 \%$ followed by genotype A (10.036\%), genotype C (7.55\%) and genotype B (5.335\%) while untypable and mixed genotypes were $2.377 \%$ and $9.931 \%$, respectively $[1,7,8,87,97-102]$. The most detailed study recently conducted by Awan et al. [96] showed that the most emerging genotype in Pakistani population is genotype $\mathrm{C}$ with the prevalence rate 
Table 2 Percent prevalence rates of HBV in Healthy Blood donors

\begin{tabular}{|c|c|c|c|c|c|c|}
\hline Population type & Region & Methods & Population size & HBV positive (\%) & HBV marker & Reference \\
\hline \multirow[t]{14}{*}{ Healthy Blood Donors } & Kurram Agency & ICT & 1300 & $5.07 \%$ & $\mathrm{HBsAg}$ & Bangash et al. [26] 2009 \\
\hline & $\begin{array}{l}\text { Interior } \\
\text { Sindh }\end{array}$ & $\mathrm{ICT}$ & 5345 & $6.2 \%$ & HBsAg & Mujeeb \& Pearce, [27] 2008 \\
\hline & Karachi & $\mathrm{ICT}$ & 11459 & $1.71 \%$ & $\mathrm{HBsAg}$ & Nazar et al. [28] 2008 \\
\hline & Karachi & $\mathrm{ICT}$ & 688 & $4.50 \%$ & $\mathrm{HBsAg}$ & Azam et al. [29] 2007 \\
\hline & Northern areas & $\mathrm{ICT}$ & 8949 & $3.66 \%$ & $\mathrm{HBsAg}$ & Alam \& Naeem, [30] 2007 \\
\hline & Karachi & $\mathrm{ICT}$ & 21,125 & $3.3 \%$ & $\mathrm{HBsAg}$ & Mujeeb \& Pearce, [31] 2007 \\
\hline & District Thatta & $\mathrm{ICT}$ & 310 & $5.81 \%$ & $\mathrm{HBsAg}$ & Ishaq et al. [32] 2007 \\
\hline & Southern Punjab & $I C T$, ELISA & 27938 & $2.69 \%$ & $\mathrm{HBsAg}$ & Khan et al. [33] 2006 \\
\hline & Lahore & $\mathrm{ICT}$ & 18216 & $3.36 \%$ & HBsAg & Sirhindi et al. [34] 2005 \\
\hline & Karachi & ELISA & 351309 & $2.0 \%$ & $\mathrm{HBsAg}$ & Akhtar et al. [35] 2005 \\
\hline & $\begin{array}{l}\text { Peshawar/ } \\
\text { KPK }\end{array}$ & MEIA & 4000 & $1.9 \%$ & $\mathrm{HBsAg}$ & Ahmad et al. [36] 2004 \\
\hline & Rawalpindi & $\mathrm{ICT}$ & 580 & $5.86 \%$ & HBsAg & Mumtaz et al. [37] 2002 \\
\hline & Northern Pakistan & ELISA & 103858 & $3.3 \%$ & $\mathrm{HBsAg}$ & Khattak et al. [38] 2002 \\
\hline & Bahawalpur & LAT, ICT & 345 & $5.64 \%$ & $\mathrm{HBsAg}$ & Fayyaz et al. [39] 2002 \\
\hline
\end{tabular}

LAT: Latex agglutination test.

of $27.66 \%$, which is a bad news as it is more common in cirrhotic patients and is known to be associated with more severe liver diseases. Moreover, Previous studies also shows that genotype D have more severe disease, less responsive to interferon therapy as compared to genotype A and B and have higher HBV DNA levels. This genotype also has specific viral sequence patterns that may predict long-term response to lamivudine treatment [101]. However, further studies are needed to characterize prevalence of different genotypes, their relative severity and treatment response rates in Pakistani population.

\section{Risk factors associated with HBV infection}

History of dialysis for more than 2 years is a risk factor for dialysis patients [90]. Major risk factors for mother to infant transmission include increasing maternal age, number of pregnancies, repeated injections and addiction [51]; major risk factors in surgical patients include re-use of contaminated syringes, contaminated surgical instruments and blood products [59]; risk factors in pregnant women (antenatal) include ear and nose prick, history of jaundice among them or with their partner [49], history of blood transfusions, history of injections

Table 3 Percent prevalence rates of HBV infection in Healthcare workers, pregnant women and pediatric population

\begin{tabular}{|c|c|c|c|c|c|c|}
\hline Population type & Region & Methods & $\begin{array}{l}\text { Population } \\
\text { size }\end{array}$ & $\begin{array}{l}\text { HBV positive } \\
(\%)\end{array}$ & HBV marker & Reference \\
\hline \multirow{2}{*}{$\begin{array}{l}\text { Health Care } \\
\text { Personals }\end{array}$} & Abbottabad & ELISA & 125 & $2.4 \%$ & $\mathrm{HBsAg}$ & Sarwar et al. [41] 2008 \\
\hline & Muzaffarabad & $\begin{array}{l}\text { RPHA, } \\
\text { ELISA }\end{array}$ & 199 & $4.1 \%$ & HBsAg & Naz et al. [42] 2002 \\
\hline \multirow[t]{9}{*}{ Pregnant women } & Karachi & $\mathrm{ICT}$ & 2592 & $0.34 \%$ & HBsAg & Sheikh, [43] 2009 \\
\hline & Swat & ICT, ELISA & 5607 & $3.98 \%$ & HBsAg & Khattak et al. [44] 2009 \\
\hline & Karachi & EIA & 5902 & $4.6 \%$ & $\mathrm{HBsAg}$ & Sami et al. [45] 2009 \\
\hline & Lahore & $I C T$, ELISA & 2439 & $2.2 \%$ & HBsAg & Batool et al. [46] 2008 \\
\hline & Bahawalpur & $I C T$, ELISA & 300 & $12.3 \%$ & $\begin{array}{l}\text { HBsAG, HBeAG, HBcAB, } \\
\text { HBsAB, }\end{array}$ & Ahmad et al. [47] 2007 \\
\hline & Karachi & $I C T$, ELISA & 25,482 & $1.57 \%$ & $\mathrm{HBs} \mathrm{Ag}$ & $\begin{array}{l}\text { Ali \& Memon, [48] } \\
2007\end{array}$ \\
\hline & Hyderabad & $I C T$, ELISA & 103 & $12.6 \%$ & HBsAg & $\begin{array}{l}\text { Yousfani et al. [49] } \\
2006\end{array}$ \\
\hline & $\begin{array}{l}\text { Rahim Yar } \\
\text { Khan }\end{array}$ & ELISA & 450 & $12.0 \%$ & HBsAg & Hakeem et al. [50] 2006 \\
\hline & Karachi & $I C T$, ELISA & 245 & $3.26 \%$ & $\mathrm{HBsAg}$ & Mehnaz et al. [51] 2002 \\
\hline \multirow[t]{2}{*}{ Children } & Karachi & ELISA & 3533 & $1.8 \%$ & HBsAg & Jafri et al. [52] 2006 \\
\hline & Lahore & $\begin{array}{l}\text { RPHA, } \\
\text { ELISA }\end{array}$ & 392 & $2.04 \%$ & HBsAg & Khan et al. [53] 1998 \\
\hline
\end{tabular}


Table 4 Percent prevalence of HBV infection in patients of different diseases in Pakistan

\begin{tabular}{|c|c|c|c|c|c|c|}
\hline Population type & Region & Methods & $\begin{array}{l}\text { Population } \\
\text { size }\end{array}$ & $\begin{array}{l}\text { HBV } \\
\text { positive(\%) }\end{array}$ & HBV marker & Reference \\
\hline \multirow[t]{4}{*}{ Surgical patients } & Karachi & EIA & 496 & $5.0 \%$ & $\mathrm{HBsAg}$ & $\begin{array}{l}\text { Moosa et al. [57] } \\
2009\end{array}$ \\
\hline & $\begin{array}{l}\text { Jacobabad } \\
\text { Sindh }\end{array}$ & $\mathrm{ICT}$ & 150 & $9.33 \%$ & $\mathrm{HBsAg}$ & $\begin{array}{l}\text { Daudpota \& Soomro, } \\
\text { [58] } 2008\end{array}$ \\
\hline & Karachi & ELISA & 387 & $6.5 \%$ & $\mathrm{HBsAg}$ & $\begin{array}{l}\text { Masood et al. [59] } \\
2005\end{array}$ \\
\hline & Karachi & $\begin{array}{l}\text { Latex method, } \\
\text { ELISA }\end{array}$ & 411 & $8.76 \%$ & $\mathrm{HBsAg}$ & $\begin{array}{l}\text { Shirazi et al. [60] } \\
2004\end{array}$ \\
\hline \multirow[t]{4}{*}{ Patients with cirrhosis } & $\begin{array}{l}\text { Saidu Sharif, } \\
\text { Swat }\end{array}$ & ELISA & 110 & $21.81 \%$ & $\mathrm{HBsAg}$ & Khan et al. [62] 2009 \\
\hline & $\begin{array}{l}\text { Dera Ismail } \\
\text { Khan }\end{array}$ & $\mathrm{ICT}$ & 60 & $46.67 \%$ & $\mathrm{HBs} A g$ & $\begin{array}{l}\text { Mashud et al. [63] } \\
2004\end{array}$ \\
\hline & Lahore & ICT, ELISA & 94 & $23 \%$ & $\begin{array}{l}\mathrm{HBsAg} \text {, anti-HBclgG, anti- } \\
\mathrm{HBs} \text {, and } \mathrm{HBeAg}\end{array}$ & Khan et al. [64] 2002 \\
\hline & Lahore & ELISA & 50 & $24 \%$ & $\mathrm{HBsAg}$ & $\begin{array}{l}\text { Hussain et al. [65] } \\
1998\end{array}$ \\
\hline \multirow{3}{*}{$\begin{array}{l}\text { Patients with Hepatocellular } \\
\text { carcinoma (HCC) }\end{array}$} & Hyderabad & ELISA & 200 & $21.0 \%$ & $\mathrm{HBsAg}$ & Ansari et al. [66] 2009 \\
\hline & Rawalpindi & $I C T$, ELISA & 44 & $25 \%$ & $\begin{array}{l}\text { anti-HBsAg, anti-HBcAb } \\
\text { antiHBeAb }\end{array}$ & $\begin{array}{l}\text { Mumtaz et al. [67] } \\
2001\end{array}$ \\
\hline & Lahore & ELISA & 30 & $20 \%$ & $\mathrm{HBsAg}$ & $\begin{array}{l}\text { Kausar et al. [68] } \\
1998\end{array}$ \\
\hline \multirow[t]{5}{*}{ Patients with hepatitis } & Rawalpindi & $\mathrm{ICT}$ & 264 & $9.8 \%$ & HBsAg & $\begin{array}{l}\text { Mumtaz \& Aftab [69] } \\
2005\end{array}$ \\
\hline & $\begin{array}{l}\text { Hyderabad/ } \\
\text { Jamshoro }\end{array}$ & ELISA & 100 & $41 \%$ & $\begin{array}{l}\text { anti-HBs } \\
\text { anti-HBC }\end{array}$ & $\begin{array}{l}\text { Almani et al. [70] } \\
2002\end{array}$ \\
\hline & Islamabad & ELISA & 2574 & $15 \%$ & $\mathrm{HBsAg}$ & $\begin{array}{l}\text { Tanwani \& Ahmad } \\
\text { [71] } 2000\end{array}$ \\
\hline & Karachi & MEIA-Abbott & 1225 & $2 \%$ & $\mathrm{HBsAg}$ & Mahmood [72] 2000 \\
\hline & Rawalpindi & $\begin{array}{l}\text { RPHA or } \\
\text { ELISA }\end{array}$ & 4315 & $11.68 \%$ & $\mathrm{HBsAg}$ & $\begin{array}{l}\text { Hussain \& } \\
\text { Ahmed [73] } 1998\end{array}$ \\
\hline \multirow[t]{4}{*}{ Patients of Liver disease } & Karachi & $\begin{array}{l}\text { ICT, ELISA, } \\
\text { PCR }\end{array}$ & 5193 & $32.6 \%$ & $\mathrm{HBsAg}$ & $\begin{array}{l}\text { Ahmed et al. [74] } \\
2010\end{array}$ \\
\hline & Peshawar & $\begin{array}{l}I C T, \text { ELISA and } \\
\text { PCR. }\end{array}$ & 181 & $18.23 \%$ & HBs Ag or DNA & Khan [75] 2006 \\
\hline & Faisalabad & ELISA & 100 & $29 \%$ & $\mathrm{HBsAg}$ & Bilal et al. [76] 2006 \\
\hline & $\begin{array}{l}\text { Hazara } \\
\text { Division }\end{array}$ & $\mathrm{ICT}$ & 893 & $30.35 \%$ & $\mathrm{HBsAg}$ & $\begin{array}{l}\text { Khan and Rizvi [77] } \\
2003\end{array}$ \\
\hline \multirow{4}{*}{$\begin{array}{l}\text { MTP (Thalassemic \& } \\
\text { Hemophiliac Children) }\end{array}$} & Islamabad & $I C T$, ELISA & 251 & $3.9 \%$ & $\mathrm{HBsAg}$ & Burki et al. [79] 2009 \\
\hline & Peshawar & ELISA & 250 & $8.4 \%$ & $\mathrm{HBsAg}$ & Shah et al. [80] 2005 \\
\hline & Peshawar & ELISA & 80 & 7.591 & $\mathrm{HBsAg}$ & $\begin{array}{l}\text { Mohammad et al. } \\
\text { [81] } 2003\end{array}$ \\
\hline & Peshawar & ELISA & 40 & $5 \%$ & $\mathrm{HBsAg}$ & $\begin{array}{l}\text { Hussain et al. [82] } \\
2003\end{array}$ \\
\hline \multirow[t]{2}{*}{ Ophthalmic Patients } & $\begin{array}{l}\text { Jamshoro/ } \\
\text { Hyderabad }\end{array}$ & $\mathrm{ICT}$ & 931 & $4.6 \%$ & $\mathrm{HBsAg}$ & $\begin{array}{l}\text { Junejo et al. [88] } \\
2009\end{array}$ \\
\hline & $\begin{array}{l}\text { Dera Ismail } \\
\text { Khan }\end{array}$ & ICT, ELISA & 1130 & $3.18 \%$ & $\mathrm{HBsAg}$ & $\begin{array}{l}\text { Ahmad et al. [89] } \\
2006\end{array}$ \\
\hline \multirow[t]{2}{*}{ IDU } & Peshawar & ELISA & 250 & $22.4 \%$ & $\mathrm{HBsAg}$ & $\begin{array}{l}\text { Alam et al. [86] } \\
\text { 2007b }\end{array}$ \\
\hline & Karachi & ELISA & 161 & $7.5 \%$ & $\mathrm{HBsAg}$ & Altaf et al. [87] 2007 \\
\hline
\end{tabular}


Table 5 Summaries of the studies conducted on prevalence of HBV genotypes in Pakistan

\begin{tabular}{|c|c|c|c|c|c|c|c|c|c|c|}
\hline Authors & Region & $\begin{array}{l}\text { Patients } \\
\text { (n) }\end{array}$ & $\begin{array}{l}\text { Genotype } \\
\text { A }\end{array}$ & $\begin{array}{l}\text { Genotype } \\
\text { B }\end{array}$ & $\begin{array}{l}\text { Genotype } \\
\text { C }\end{array}$ & $\begin{array}{l}\text { Genotype } \\
\text { D }\end{array}$ & $\begin{array}{l}\text { Genotype } \\
\text { E }\end{array}$ & $\begin{array}{l}\text { Genotype } \\
\mathrm{F}\end{array}$ & Untypable & Mixed \\
\hline $\begin{array}{l}\text { Awan et al. } \\
\text { [96] } 2010\end{array}$ & $\begin{array}{l}\text { All areas of } \\
\text { Pakistan }\end{array}$ & 300 & $\begin{array}{l}43 \\
(14.33 \%)\end{array}$ & $54(18 \%)$ & $\begin{array}{l}83 \\
(27.66 \%)\end{array}$ & $39(13 \%)$ & $2(0.66 \%)$ & $4(1.33 \%)$ & $\begin{array}{l}31 \\
(10.33 \%)\end{array}$ & $\begin{array}{l}44 \\
(14.66 \%)\end{array}$ \\
\hline $\begin{array}{l}\text { Ahmed et al. } \\
\text { [97] } 2009\end{array}$ & Punjab and Sindh & 236 & $2(0.85 \%)$ & - & $\begin{array}{l}14 \\
(5.93 \%)\end{array}$ & $\begin{array}{l}220 \\
(93.22 \%)\end{array}$ & - & - & - & - \\
\hline $\begin{array}{l}\text { Baig et al. } \\
\text { [98] } 2009\end{array}$ & Karachi & 315 & $65(20 \%)$ & - & - & 219 (70\%) & - & - & - & $\begin{array}{l}31 \\
(10 \%)\end{array}$ \\
\hline $\begin{array}{l}\text { Noorali et al. } \\
\text { [7] } 2008\end{array}$ & Karachi & 180 & - & - & - & $\begin{array}{l}150 \\
(83.33 \%)\end{array}$ & - & - & - & $\begin{array}{l}30 \\
(16.66 \%)\end{array}$ \\
\hline $\begin{array}{l}\text { Hakim et al. } \\
\text { [8] } 2008\end{array}$ & Karachi & 180 & - & - & - & $\begin{array}{l}151 \\
(83.89 \%)\end{array}$ & - & - & - & $\begin{array}{l}29 \\
(16.11 \%)\end{array}$ \\
\hline $\begin{array}{l}\text { *Alam et al. } \\
\text { [99] } 2007\end{array}$ & $\begin{array}{l}\text { Patients from All } \\
\text { four Provinces }\end{array}$ & 110 & $5(4.55)$ & $27(24.54 \%)$ & - & $66(60 \%)$ & - & - & $9(8.18 \%)$ & $\begin{array}{l}3 \\
(2.73 \%)\end{array}$ \\
\hline $\begin{array}{l}\text { Baig et al. } \\
\text { [100] } 2007\end{array}$ & Karachi & 295 & $\begin{array}{l}60 \\
(20.34 \%)\end{array}$ & - & - & $\begin{array}{l}208 \\
(70.51 \%)\end{array}$ & - & - & - & $\begin{array}{l}27 \\
(9.15 \%)\end{array}$ \\
\hline $\begin{array}{l}\text { Alam et al. } \\
\text { [86] } 2007\end{array}$ & KPK & 56 & $15(8.92 \%)$ & - & - & 35 (62.5\%) & - & - & - & $\begin{array}{l}16 \\
(28.57 \%)\end{array}$ \\
\hline $\begin{array}{l}\text { Abbas et al. } \\
\text { [101] } 2006\end{array}$ & Karachi & 109 & - & - & - & 109 (100\%) & - & - & - & - \\
\hline $\begin{array}{l}\text { Idrees et al. } \\
\text { [1] } 2004\end{array}$ & $\begin{array}{l}\text { Patients from All } \\
\text { four Provinces }\end{array}$ & 112 & $\begin{array}{l}24 \\
(21.42 \%)\end{array}$ & $\begin{array}{l}20 \\
(17.86 \%)\end{array}$ & $\begin{array}{l}46 \\
(41.07 \%)\end{array}$ & 9 (8.03\%) & - & - & $5(4.46 \%)$ & $\begin{array}{l}8 \\
(7.14 \%)\end{array}$ \\
\hline Total & & 1893 & $\begin{array}{l}190 \\
(10.03 \%)\end{array}$ & $\begin{array}{l}101 \\
(5.335 \%)\end{array}$ & $\begin{array}{l}143 \\
(7.55 \%)\end{array}$ & $\begin{array}{l}1206 \\
(63.71 \%)\end{array}$ & $2(0.105 \%)$ & $4(0.21 \%)$ & $\begin{array}{l}45 \\
(2.377 \%)\end{array}$ & $\begin{array}{l}188 \\
(9.931 \%)\end{array}$ \\
\hline
\end{tabular}

KPK: Khyber Pakhtunkhwa Province.

*The percentage values are different in the original manuscript as the authors considered the untypable samples as negative for genotype.

$[46,49]$, tooth extraction [46]; in prisoners significant risk factors were intravenous drug abuse [24,25], rural origin and shaved by barber [25]; in orthopedic patients common risk factors are previous history of surgery or blood transfusion [94]. Major risk factors for health care workers are dental procedures, needle prick and surgical procedures [41]; most important risk factors for HBV infection in young recruits were sharing of razors, history of intravenous injections, jaundice in the subject and jaundice in family [22]; in children key risk factors were injection in the past, surgical and dental procedures, blood transfusion, accidental cuts at barber shops and umbilical cord cut through unsterilized instruments at home [102]; in thalassaemic children there is a definite risk factor of repeated blood transfusion [79], while main risk factors among the obstetrical and gynecological population were unsafe surgery, injections and inadequately screened blood transfusions [45]. Qureshi et al. [103] compared male patients suffering from chronic hepatitis with healthy people as control and found very strong relationship of the HBV infection with history of dental treatment, surgery and history of taking injections. It is established fact that HBsAg does not cross the placental barrier however; the infection in children/ newborns may occur at the time of birth or soon after birth. The infants of HBV positive mothers must be vaccinated soon after birth and HBIG immediately within 24 hours of birth [54]. Relatively low prevalence in the female prostitutes (high risk group) reflects the effect of legal, social and religious constraints in Pakistani society [56]. Many of the Afghan refuges (most of them are children) are rag pickers who collect used syringes and needles dumped outside the hospitals and hence are one of the most vulnerable groups to viral hepatitis in Pakistan [104]. Most of these factors are easily preventable and need awareness in general population and the healthcare workers.

Preventive strategies for HBV infection include healthy blood transfusion services along with safe sex [34], vaccination against HBV $[40,103]$, shaving by barbers needs to be discouraged [103] and better training of healthcare workers [105]. Paid blood donation should be prohibited [85]. All patients needing surgery should be screened for viral hepatitis and there should be separate operation theatres facilities for these patients [94]. In addition reuse of razors in many barber shops that may spread hepatitis in a substantial number of individuals [106] and must be discouraged. Importantly, the most common risk factors and modes of HBV transmission in this country differ in importance in various community groups [23].

In Turkish population, HLA-A24 and Cw1 has been associated with low risk for HBV-related chronic liver disease and HLA- B13, B8, DR7, DR13 and DQ3 were found associated with high risk for chronic HBV infection [107]. However, there is no study that describes cellular or molecular mechanism of HBV infection in Pakistani population. 


\section{Awareness about HBV in Pakistani population}

Nasim et al. [108] conducted a questioner bases survey in Karachi to assess knowledge about viral hepatitis among college girls and showed that $57 \%$ of them do not have information about transmission of hepatitis B virus. In another survey [109] at obstetric and gynecology clinic at Hyderabad showed that most of the women (67.76\%) know that HBV is a viral disease, $75.20 \%$ responded that it affect liver, $33.88 \%$ believed that it could be transmitted by infected blood transfusion, $17.35 \%$ believed that it could be transmitted from mother to child, $19.0 \%$ mentioned sexual intercourse responsible for HBV infection, while $40.49 \%$ and $38.0 \%$ mentioned contaminated needles and un-sterilised instruments as a source of HBV infection, respectively. Mengal et al. [110] surveyed nursing students at nursing school, Bolan medical complex hospital, Quetta and reported that only $37.2 \%$ of them were completely vaccinated and $25.0 \%$ had not been vaccinated for HBV. Chaudhry et al. [111] repoted that $97.4 \%$ of the barbers at Islamabad use new blade for every customer but only $38 \%$ of them has knowledge about routes of infection of HBV and HCV. In another study, Waheed et al. [112] reported that $39.6 \%$ of the barbers at Rawalpindi and Islamabad knew that Hepatitis B and hepatitis $C$ were viral diseases, 90.7\% thought that hepatitis could spread by blade sharing, $26.6 \%$ knew that it can lead to cancer and $47.8 \%$ knew that a vaccine for HBV was available. Ali et al. [113] reported that $78.8 \%$ of the rural population of Faisalabad was unaware of viral hepatitis. In another study, Asif et al. [114] reported that only 17.6\% of the rural population of Nowshera was aware of the fact that Hepatitis B and C are transmitted by a virus. Talpur et al. [115] stated that there is significant lack of knowledge and poor attitude towards $\mathrm{HBV}$ and $\mathrm{HCV}$ in surgical patients at Nawabshah area. We suggest aggressive public awareness programs especially in rural areas and people at high risk to decrease the burden of HBV infection in Pakistan.

\section{Conclusions}

This article reviews prevalence of HBV in different areas and population groups in Pakistan, along with awareness status, risk factors and genotypes in Pakistani population. Prevalence of HBV infection varies with population residing in different regions of Pakistan. The present literature shows that Afghan refuges in Pakistan, IDUs, professional blood donors, health care professionals, prisoners, multiple transfused patients, patients with HCC, psychiatric patients, general population of some specific areas like Southern Punjab, Interior Sindh, District Tatta, Kurrum agency, Baltistan and some areas of Lahore have very high HBV prevalence of more than $5 \%$, and there is urgent need of mass vaccination and awareness programs. Further studies are needed to characterize HBV prevalent in Pakistan at molecular level. Moreover, both host and viral factors associated with molecular and cellular mechanism of HBV infection in Pakistani population needs to be explored.

\section{Authors' contributions}

$\mathrm{MA}$ and $\mathrm{Ml}$ conceived the study and designed the inclusion criteria. MA searched the literature and drafted the manuscript. MI, IR and AH critically reviewed the manuscript. IR, SS, SA, SB and LA helped MA in literature search, data extraction and statistical analysis. All the authors read and approved the final manuscript.

\section{Competing interests}

The authors declare that they have no competing interests.

Received: 2 February 2011 Accepted: 6 March 2011

Published: 6 March 2011

\section{References}

1. Idrees $M$, khan S, Riazuddin S: Common genotypes of hepatitis B virus. J Coll Phy Sur Pak 2004, 14:344-7.

2. Zhu R, Zhang H, Yu H, Li H, Ling YQ, Hu XQ, Zhu HG: Hepatitis B virus mutations associated with in situ expression of hepatitis B core antigen, viral load and prognosis in chronic hepatitis B patients. Pathol Res Pract 2008, 204:731-742.

3. Ali L, Idrees M, Ali M, Rehman I, Hussain A, Afzal S, Butt S, Saleem S, Munir S, Badar S: An overview of treatment response rates to various anti-viral drugs in Pakistani Hepatitis B Virus infected patients. Virology J 2011, 8:20.

4. Li G, Li W, Guo F, Xuc S, Zhaod N, Chena S, Liu L: A novel real-time PCR assay for determination of viral loads in person infected with hepatitis $B$ virus. J Virol Meth 2010, 165:9-14.

5. Paraskevis D, Haida C, Tassopoulos N, Raptopoulou M, Tsantoulas D, Papachristou H, Sypsa V, Hatzakis A: Development and assessment of a novel real-time PCR assay for quantitation of HBV DNA. J Virol Meth 2002, 103:201-212.

6. Alam MM, Zaidi SZ, Malik SA, Naeem A, Shaukat S, Sharif S, Angez M, Khan A, Butt JA: Serology based disease status of Pakistani population infected with Hepatitis B virus. BMC Infect Dis 2007, 7:64.

7. Noorali S, Hakim ST, McLean D, Kazmi SU, Bagasra O: Prevalence of Hepatitis B virus genotype D in females in Karachi, Pakistan. J Infect Developing Countries 2008, 2:373-378.

8. Hakim ST, Kazmi SU, Bagasra O: Seroprevalence of Hepatitis B and C Genotypes Among Young Apparently Healthy Females of KarachiPakistan. Libyan J Med 2008, 3:66-70.

9. Hepatitis prevention \& control program Sindh (chief minister's initiative) 2009. directorate general health services, Hyderabad, Sindh, Pakistan.

10. Nafees $M$, Farooq $M$, Jafferi $G$ : Frequency of hepatitis $B$ and $C$ infections in the general population of Lahore, Pakistan. Biomedica 2009, 25:106-11.

11. Shaikh EM, Naz S, Bhatti A, Shaikh MA, Shaikh R, Shaikh WM, Laghari KN: Seroprevalence of hepatitis B \& C at shaikh zaid women hospital larkana. Medical channel 2009, 15:161-163.

12. Tanveer A, Batool K, Qureshi AW: Prevalence of hepatitis B and $c$ in university of the Punjab, Quaid-e-azam campus, Lahore. ARPN J Agri Bio Sci 2008, 3:30-32.

13. Mirza IA, Kazmi SMH, Janjua AN: Frequency of hepatitis B surface antigen and anti-HCV in young adults - experience in southern Punjab. J Coll Phy Sur Pak 2007, 17:114-115.

14. Alam M, Tariq WZ, Akram S, Qureshi TZ: Frequency of hepatitis B and C in central Punjab. Pak J Pathol 2006, 17(4):140-141.

15. Faroog MA, Iqbal MA, Tariq WZ, Hussain AB, Ghani I: Prevalence of hepatitis B and C in a healthy cohort. Pak J Pathol 2005, 16:42-46.

16. Amin J, Yousuf H, Mumtaz A, labal M, Ahmed R, Adhami SZ, Malik K: Prevalence of hepatitis $B$ surface antigen and anti hepatitis $C$ virus among general population in Lahore. Prof Med J 2004, 11:334-7.

17. Qasmi SA, Aqeel S, Ahmed M, Alam Sl, Ahmad A: Detection of hepatitis B viruses in normal individuals of Karachi. J Coll Phy Sur Pak 2000, 10:467-9. 
18. Azam N, Mufti K, Zafar N: Frequency of hepatitis b \& c in young male recruits from rural Pakistan. Pak Arm Forc Med J 2009, 2:59-64.

19. Malik N, Butt T, Mansoor N, Khan TG, Akbar MS, Asl M: Percentage of hepatitis $B$ and $C$ among young adult males from interior Sindh. Pak Arm Forc Med J 2008, 58:260-266.

20. Sherif T, Tariq WZ: Seroprevalence of hepatitis B and C in healthy adult male recruits. Pak J Pathol 2006, 17:147-150

21. Mirza IA, Mirza SH, Irfan S, Siddiqi R, Tariq WZ, Janjua AN: Seroprevalence of Hepatitis B and $C$ in young adults seeking recruitment in armed forces. Pak Arm Forc Med J 2006, 56:192-197.

22. Hussain AB, Hashim R, Rehman K: Hepatitis B surface antigen. Prof Med J 2005, 12:213-217.

23. Ali N, Khattak J, Anwar M, Tariq WZ, Nadeem M, Irfan M, Asif M, Hussain AB: Prevalence of hepatitis $B$ surface antigen and hepatitis $C$ antibodies in young healthy adults. Pak J Pathol 2002, 13:3-6.

24. Kazi AM, Shah SA, Jenkins CA, Shepherd BE, Vermund SH: Risk factors and prevalence of tuberculosis, human immunodeficiency virus, syphilis, hepatitis B virus, and hepatitis C virus among prisoners in Pakistan. Int J Infect Dis 2010, 14S:e60-e66.

25. Fayyaz M, Qazi MA, Ishaq M, Chaudhary G M, Bukhari MH: Frequency of hepatitis B and C seropositivity in prisoners. Biomedica 2006, 22:55-8.

26. Bangash $M H$, Bangash $T H$, Alam S: Prevalance of hepatitis $B$ and hepatatis C among healthy blood donors at Kurram agency. J Postgrad Med Inst 2009, 23:140-5.

27. Mujeeb SA, Pearce MS: Temporal trends in hepatitis $B$ and $C$ infection in family blood donors from interior Sindh, Pakistan. BMC Infect Dis 2008, $8: 43$.

28. Nazar H, Nadia N, Shazia N, Zulfiqar A, Farhat A: Prevalence of Hepatitis B and Hepatitis C in blood donors of Karachi. Biomedica 2008, 24:116-117.

29. Azam M, Jamal N, Imtiaz F, Haque Z, Ayoob Z: Blood donor screening for hepatitis and HIV. J Dow Uni Health Sci 2007, 1:82-83.

30. Alam M, Naeem MA: Frequency of hepatitis B surface antigen and antihepatitis $C$ antibodies in apparently healthy blood donors in Northern areas. Pak J Pathol 2007, 18:11-14.

31. Mujeeb SA, Pearce MS: Seroprevalence and determinants of risk of Hepatitis B and C viral infections in blood donors: A cross sectional analytic study. J Infect Developing Countries 2007, 1:17-24.

32. Ishaq M, Ali SS, Karim N, Umrani NI, Hassan N: Frequency of hepatitis B and $\mathrm{C}$ virus among the healthy volunteer blood donors at Taulka hospital Sujjawal, District Thatta, Sindh. Ann Abbasi Shaheed Hosp Karachi Med Dent Coll 2007, 12:97-101.

33. Khan MA, Chaudhary GM, Fayyaz M, Qazi MA, Ahmed G: Hepatitis B, C \& HIV; seroprevalence of infection in blood donors. Professional Med J 2006, 13:632-636.

34. Sirhindi GA, Khan AA, Alam SS, Ghori MA, Rehman R, Soomro NA Ahmed Z, Naeem MS, Shah WH, Hussain A, Chohan RA: Frequency of Hepatitis B, C and human immunodeficiency virus in blood donors at Shaikh Zayed hospital, Lahore. Proceeding Shaikh Zayed Postgrad Med Inst 2005, 19:33-6.

35. Akhtar S, Younus M, Adil S, Hassan F, Jafri SH: Epidemiologic study of chronic hepatitis $B$ virus infection in malevolunteer blood donors in Karachi, Pakistan. BMC Gastroenterol 2005, 5:26.

36. Ahmad J, Taj AS, Rahim A, Shah A, Rehman M: Frequency of hepatitis B and hepatitis $C$ in healthy blood donors of NWFP: A single center experience. J Postgrad Med Inst 2004, 18:343-52.

37. Mumtaz $S$, Rehman M, Muzaffar M, Hassan M, labal W: Frequency of seropositive blood donors for hepatitis $B, C$ and HIV viruses in railway hospital Rawalpindi. Pak J Med Res 2002, 41:51-3.

38. Khattak MF, Salamat N, Bhatti FA, Qureshi TZ: Seroprevalence of hepatitis B, C and HIV in blood donors in northern Pakistan. J Pak Med Assoc 2002, 52:398-402.

39. Fayyaz KM, Ali S, Khan AA, Shafique M, Khan MA, Majeed S, Butt AS: Hepatitis B carriers; diagnosis among volunteer blood donor students at Quaid-i-Azam medical college Bahawalpur. Professional Med J 2002, 9:186-90.

40. Ahmed M: Hepatitis B surface antigen study in professional and volunteer blood donors. Ann Abbasi Shaheed Hosp Karachi Med Dent Coll 2001, 6:304-306.

41. Sarwar J, Gul N, Idris M, Rehman A, Farid J, Adeel MY: Seroprevalence of hepatitis B and hepatitis C in healthcare workers in Abbottabad. J Ayub Med Coll Abottabad 2008, 20:27-29.
42. Naz S, Ahmad M, Agha H: Prevalence of hepatitis 'B' among hospital personnel in Combined Military Hospital (CMH) Muzaffarabad. Int J Agri Biol 2002, 4:227-230.

43. Sheikh SM: Hepatitis B and C: value of universal antenatal screening. J Coll Phy Sur Pak 2009, 19:179-82.

44. Khattak ST, Marwat MA, Khattak I, Khan TM, Naheed T: Comparison of frequency of hepatitis $B$ and hepatitis $C$ in pregnant women in urban and rural area of district Swat. J Ayub Med Coll Abottabad 2009, 21:12-5.

45. Sami S, Korejo R, Bhutta SZ: Prevalence of hepatitis B and C: A Jinnah postgraduate medical centre experience. J Obstetrics and Gynecology Res 2009, 35:533-538.

46. Batool A, Bano KA, Khan Ml, Hussain R: Antenatal screening of women for hepatitis B and C in an out-patient department. J Dow Uni Health Sci 2008, 2:32-5.

47. Ahmad A, Khichi GQ, Rehman A: Hepatitis B markers. Professional Med J 2007, 1:307-311.

48. Ali HS, M Memon A: Prevalence of hepatitis B infection in pregnant women in a tertiary care hospital. J Infect Dis Pak 2007, 16:35-38,

49. Yousfani S, Mumtaz F, Memon A, Memon MA, Sikandar R: Antenatal screening for hepatitis B and C virus carrier state at a university hospital. JLUMHS 2006, 5:24-27.

50. Hakeem A, M Khan S, Abdullah M, Rehman A, Hashmi Ml: Prevalence of $\mathrm{HbsAg} \&$ Anti HCV in pregnant ladies attending antenatal clinic at Sheikh Zayed Medical Complex, Rahim Yar Khan. Esculapio 2006, 2:6-8.

51. Mehnaz A, Hashmi H, Syed S, Kulsoom : Hepatitis B markers in mothers and its transmission in newborn. J Coll Phy Sur Pak 2002, 12:240-2.

52. Jafri W, Jafri N, Yakoob J, Islam M, Tirmizi SF, Jafar T, Akhtar S, Hamid S, Shah HA, Nizami SQ: Hepatitis B and C: prevalence and risk factors associated with seropositivity among children in Karachi, Pakistan. BMC Infect Dis 2006, 6:10.

53. Khan MA, Ali AS, Hassan Z, Mir F, Haque S: Seroprevalence of hepatitis B in children. Pak Paed J 1998, 22:75-77.

54. Kazmi K, Ghafoor A, Qureshi WA: Mother-infant transmission of hepatitis B in Pakistan. Pak J Med Res 2003, 42:152-6.

55. Quddus A, Luby S, Jamal Z, Jafar T: Prevalence of hepatitis B among Afghan refugees living in Balochistan, Pakistan. Int J Infect Dis 2006, 10:242-247.

56. Anwar MS, Jaffery G, Rasheed A: Serological screening of female prostitutes for anti-HIV and hepatitis B surface antigen. Pak J Health 1998, 35:69-73.

57. Moosa FA, Shaikh BA, Choudhry MS, Zuberi BF, Khan FW, Sultan N: Frequency of hepatitis $B$ and $C$ in pre-operative patients for elective surgery. JLUMHS 2009, 8:150-152.

58. Daudpota AQ, Soomro AW: Sero prevalence of hepatitis B and C in surgical patients. Pak J Med Sci 2008, 24:483-484.

59. Masood Z, Jawaid M, Khan RA, Rehman S: Screening for hepatitis B \& C: A routine preoperative investigation. Pak J Med Sci 2005, 21:455-9.

60. Shirazi B, Jaffery AH, Kishwar M, Shamim MS: Screening for hepatitis B \& C in surgical patients. J Coll Phy Sur Pak 2004, 9:10-3.

61. Chaudhary IA, Khan SA, Samiullah : Should we do hepatitis B and C screening on each patient before surgery: Analysis of 142 cases. Pak J Med Sci 2005, 21:278-80.

62. Khan P, Ahmad A, Muhammad N, Khan TM, Ahmad B: Screening of 110 cirrhotic patients for hepatitis B and C at Saidu teaching hospital Saidu sharif Swat. J Ayub Med Coll Abbottabad 2009, 21:119-121.

63. Mashud I, Khan H, Khattak AM: Relative frequency of hepatitis B and C viruses in patients with hepatic cirrhosis at DHQ teaching hospital DI Khan. J Ayub Med Coll Abottabad 2004, 16:32-4.

64. Khan AA, Rehman K, Haider Z, Shafqat F: Seromarkers of hepatitis B and C in patients with cirrhosis. J Coll Phy Sur Pak 2002, 12:105-7.

65. Hussain I, Nasrullah M, Shah AA: Prevalence of hepatitis B and C viral infections in liver cirrhosis in Pakistan. Pak J Gastroenterol 1998, 12:7-11.

66. Ansari S, Memon MS, Devrajani BR: Frequency of hepatitis B and hepatitis C in patients with hepatocellular carcinoma at Hyderabad. JLUMHS 2009, 8:109-12.

67. Mumtaz MS, lqbal R, Umar M, Khar B, Mumtaz MO, Anwar F, Zulfiqar S, Ejaz S, Hanif S, Khan MA, Mazhar S, Abassi S: Sero-prevalence of hepatitis B and C viruses in hepatocellular carcinoma. J Rawal Med Coll 2001, 5:78-80.

68. Kausar S, Shafqat F, Shafi F, Khan AA: The association of hepatocellular carcinoma with hepatitis B and C viruses. Pak J Gastroenterol 1998, 12:1-2. 
69. Mumtaz S, Aftab I: Seromarkers of hepatitis B \& C viruses observed in symptomatic cases of teaching hospital of IIMC (Railway Hospital) Rawalpindi. Ann Pak Inst Med Sci 2005, 1:242-4.

70. Almani SA, Memon AS, Qureshi AF, Memon NM: Hepatitis viral status in Sindh. Professional Med J 2002, 9:36-43.

71. Tanwani AK, Ahmad N: Prevalence of hepatitis B surface antigen and anti-hepatitis C virus in laboratory based data at Islamabad. J Surg 2000, 20:25-29.

72. Mahmood A: Hepatitis B Virus: Prevalence in Karachi. J Coll Phy Sur Pak 2000, 10:107-108.

73. Hussain T, Ahmed SZ: Acute hepatitis B - Serological confirmation. Pak Armed Forces Med J 1998, 48:102-5.

74. Ahmed W, Arif A, Alam SE, Qureshi H: Changing trend of viral hepatitis-"A twenty one year report from Pakistan medical research council research centre, Jinnah postgraduate medical centre, Karachi". J Pak Med Assoc 2010, 61:86-89.

75. Khan H: Liver disease pattern in a tertiary care hospital of Peshawar, Pakistan. Hepatitis Monthly 2006, 6:85-86.

76. Bilal A, Qureshi FS, Omar Z, Khalid G: Frequency of hepatitis B and C virus in patients with decompensated cirrhosis of liver in Faisalabad. Pak $J$ Gastroenterol 2006, 20:43-48.

77. Khan TS, Rizvi F: Hepatitis B seropositivity among chronic liver disease patients in Hazara Division Pakistan. J Ayub Med Coll Abottabad 2003, 15:54-5.

78. Waheed Y, Shafi T, Safi SZ, Qadri I: Hepatitis C virus in Pakistan: A systematic review of prevalence, genotypes and risk factors. World J Gastroenterol 2009, 15:5647-5653.

79. Burki MF, Hassan M, Ali L, Wadood MZ: Frequency of hepatitis B virus in regularly blood transfused beta thalassemia major patients. Pak Paed $J$ 2009, 33:153-156.

80. Shah MA, Khan MT, Ulla Z, Ashfaq Y: Prevalence of hepatitis B and hepatitis $C$ virus infection in multi-transfused thalassemia major patients in North West Frontier Province. Pak J Med Sci 2005, 21:281-3.

81. Mohammad J, Hussain M, Khan MA: Frequency of hepatitis B and hepatitis C infection in thalassemic children. Pak Paed J 2003, 27:161-4.

82. Hussain M, Khan MA, Mohammad J, Jan A: Frequency of hepatitis B and C in hemophiliac children. Pak Paed J 2003, 27:157-60.

83. UNESCAP: Taking it to the streets: A harm reduction program for Pakistani drug users (Nai Zindagi, Pakistan). HIV/AIDS Prevention, Care and Support: Stories from the Community; 2010 [http://www.unescap.org/ esid/hds/pubs/2249/p1e.pdf].

84. Strathdee SA, Zafar T, Brahmbhatt H, Baksh A, Hassan S: Rise in needle sharing among injection drug users in Pakistan during the Afghanistan war. Drug Alcohol Depend 2003, 71:17-24.

85. Ahmed MA, Zafar T, Brahmbhatt H, Imam G, UI Hassan S, Bareta JC Strathdee SA: HIV/AIDS risk behaviors and correlates of injection drug use among drug users in Pakistan. J Urban Health 2003, 80:321-329.

86. Alam MM, Zaidi SZ, Shaukat S, Sharif S, Angez M, Naeem A, Saleha S, Butt JA, Malik SA: Common genotypes of hepatitis $B$ virus prevalent in injecting drug abusers (addicts) of North West Frontier Province of Pakistan. Virol J 2007, 4:63.

87. Altaf A, Shah SA, Zaidi NA, Memon A, Rehman N, Wray N: High risk behaviors of injection drug users registered with harm reduction programme in Karachi, Pakistan. Harm Reduct J 2007, 4:7.

88. Junejo SA, Khan NA, Lodhi AA: Prevalence of hepatitis B and C infection in patients admitted at tertiary eye care centre: A hospital based study. Pak J Med Sci 2009, 25:597-600.

89. Ahmad I, Khan SB, Rehman H, Khan MH, Anwar S: Frequency of hepatitis B and hepatitis C among cataract patients. Gomal J Med Sci 2006, 4:61-64.

90. Khokhar N, Alam AY, Naz F: Hepatitis B surface antigenemia in patients on hemodialysis. Rawal Med J 2004, 29:18-21.

91. Mumtaz A, Salaria SM, Bukhari SH, Khan NS: Study of hepatitis 'B' antigenaemia in government hospital for psychiatric diseases. Ann King Edward Med Coll 2002, 8:167-8.

92. Tayyab GN, Arfeen N, Ahmad U, Hafeez A: Seroprevalence of hepatitis B in patients suffering from hepatitis in Lahore, Pakistan. Pak J Gastroenterol 1999, 13:5-7.

93. Mahboob A, Haroon TS, Iqbal Z, Saleemi MA, Munir A: Prevalence of hepatitis B surface antigen carrier state in patients with lichen planus report of 200 cases from Lahore, Pakistan. J Ayub Med Coll Abottabad 2007, 19:68-70.
94. Khan MS, Jamil M, Jan S, Zardad S, Sultan S, Sahibzada AS: Prevalence of hepatitis ' $B$ ' and ' $C$ ' in orthopaedics patients at Ayub teaching hospital Abbottabad. J Ayub Med Coll Abottabad 2007, 19:82-84.

95. Price, Boxall : Treatment of children persistently infected with hepatitis B virus: seroconversion or suppression. J Antimicrob Chemother 2007, 60:1189-1192.

96. Awan Z, Idrees M, Amin I, Butt S, Afzal S, Akbar H, Rehman IU, Younas S, Shahid M, Lal A, Saleem S, Rauff B: Pattern and molecular epidemiology of hepatitis B virus genotypes circulating in Pakistan. Infect Genet Evol 2010, 10:1242-6.

97. Ahmed CS, Wang ZH, Bin Z, Chen JJ, Kamal M, Hou JL: Hepatitis B virus genotypes, subgenotypes, precore, and basal core promoter mutations in the two largest provinces of Pakistan. J Gastroenterol Hepatol 2009, 24:569-73.

98. Baig S, Siddiqui A, Chakravarty R, Moatter T: Hepatitis B virus subgenotypes D1 and D3 are prevalent in Pakistan. BMC Res Notes 2009, 2:1.

99. Alam MM, Zaidi SZ, Malik SA, Shaukat S, Naeem A, Sharif S, Angez M, Butt JA: Molecular epidemiology of hepatitis B virus genotypes in Pakistan. BMC Infect Dis 2007, 7:115.

100. Baig S, Siddiqui AA, Ahmed W, Qureshi H, Arif A: The association of complex liver disorders with HBV genotypes prevalent in Pakistan. Virology J 2007, 4:128.

101. Abbas Z, Muzaffar R, Siddiqui A, Naqvi AA, Rizvi AH: Genetic variability in the precore and core promoter regions of hepatitis $B$ virus strains in Karachi. BMC Gastroenterol 2006, 6:20.

102. Khan A, Ageel M, Tariq SM, Khattak AA: Frequency of hepatitis B surface antigen and its association with possible risk factors in hospitalized pediatric patients. Pak Paed J 2009, 3:39-43.

103. Qureshi H, Arif A, Riaz K, Alam SE, Ahmed W, Mujeeb SA: Determination of risk factors for hepatitis $B$ and $C$ in male patients suffering from chronic hepatitis. BMC Res Notes 2009, 2:212.

104. Ahmad K: Pakistan: a cirrhotic state? The Lancet 2004, 364:1843-1844.

105. Aziz S, Memon A, Tily HI, Rasheed K, Jehangir K, Quraishy MS: Prevalence of HIV, hepatitis B and C amongst health workers of civil hospital Karachi. J Pak Med Assoc 2002, 52:92-4.

106. Janjua NZ, Nizamy MAM: Knowledge and practices of barbers about hepatitis B and C transmission in Rawalpindi and Islamabad. J Pak Med Assoc 2004, 54:116-9.

107. Karan MA, Tascioglu C, Erten N, Ozturk AO, Palanduz S, Carin M: The role of HLA antigens in chronic hepatitis B virus infection. J Pak Med Assoc 2002, 52:253-6.

108. Nasim S, Shahid A, Pirzada AG, Memon AA: Perception of adolescent females about viral hepatitis in urban and rural Sindh. Pak J Med Res 2009, 48:71-3.

109. Haider G, Haider A: Awareness of women regarding hepatitis B. J Ayub Med Coll Abbottabad 2008, 20:141-144.

110. Mengal $H$, Howteerakul N, Suwannapong N, Rajatanun T: Factors relating to acceptance of hepatitis B virus vaccination by nursing students in a tertiary hospital, Pakistan. J Health Popul Nutr 2008, 26:46-53.

111. Chaudhry MA, Rizvi F, Ashraf MZ, Afzal M, Niazi S: Knowledge and practices of barbers regarding hepatitis B and hepatitis C in Bahra Kahu, Islamabad-Pakistan. Rawal Med J 2010, 35:37-40.

112. Waheed Y, Saeed U, Safi SZ, Chaudhry WN, Qadri I: Awareness and risk factors associated with barbers in transmission of hepatitis B and C from Pakistani population: barber's role in viral transmission. Asian Biomedicine 2010, 4:435-442.

113. Ali A, Akhtar S, Saqi SK: Awareness of viral hepatitis among people of rural areas of Faisalabad, Pakistan. Pak J life Soc Sci 2004, 2:57-58.

114. Asif SA, lqbal R, Hussain $H$, Khan MH: Awareness of viral hepatitis in ten villages of district Nowshera. Gomal J Med Sci 2009, 7:10-13.

115. Talpur AH, Memon NA, Solangi RA: Knowledge and attitude of patients towards hepatitis B and C. Pak J Surg 2007, 23:162-165.

doi:10.1186/1743-422X-8-102

Cite this article as: Ali et al: Hepatitis B virus in Pakistan: A systematic review of prevalence, risk factors, awareness status and genotypes. Virology Journal 2011 8:102. 